Mr. Bacharach's other suggestion is worthy of consideration, but I have not heard of anyone producing refection in mice.

To Dr. Coward: Refection is an extremely eapricious phenomenon; while it may flourish in its various forms in one laboratory, as shown by Dr. Harris, it may resolutely refuse to appear in another. I have never had spontaneous rice starch refection in my laboratory even in the presence of well established potato starch refection.

REFERENCE

Kon, P. M., Kon, S. K. and Mattick, A. T. R. (1938). J. Hyg., Camb., 38, 1.

\title{
The Production and Absorption of the Volatile Acids in the Rumen
}

Mrs. R. A. Marshall and Dr. A. T. Phillipson (Agricultural Research Council Unit of Animal Physiology, Department of Physiology, Cambridge)

Gastric digestion, by which is usually understood peptic digestion, occurs only in the fourth part of the stomach of the ruminant. The suale on which this process proceeds is not known and it is in any case applicable only to protein. Apart from this question gastric digestion in the ruminant has a wider interpretation, since the rumen and reticulum together form an incubator in which the substrate is food, the digestive agents bacteria, and the end products of digestion, as far as is certainly ascertained, a mixture of the lower fatty acids together with methane. Gastric digestion in the ruminant therefore consists primarily of the fermentation of carbohydrate which is followed by true peptic digestion.

The scale on which fermentation in the rumen proceeds can be appreciated when the following points are considered.

(a) If grass is taken as a standard foodstuff, the carbohydrates eaten by ruminants, and indeed all herbivorous animals, are for the most part digestible only by the aid of bacteria. The ability of the ruminant to digest as much as 50 per cent. of the crude fibre of wheat straw and a higher proportion of the crude fibre of grass is indicative of the efficiency of the process of fermentation in the rumen.

(b) The caloric requirements of ruminants are obtained for the most part from the carbohydrate of the diet and, at grass, a $50 \mathrm{~kg}$. sheep will eat about $860 \mathrm{~g}$. carbohydrate a day of which about 75 per cent. is digested.

(c) The amount of ingesta found in the rumen and reticulum together forms a large proportion of the whole quantity of ingesta in the alimentary tract. In the sheep we have found the proportion contained in these 2 parts of the stomach to vary from 55 to 75 per cent. of the whole, while Washburn and Brodie (1937) obtained figures that exceed this range, their highest figure being 85 per cent. In the ox on the other hand the proportion is slightly less and 2 values we obtained were 40 and 42 per cent. This is due not to a smaller comparative capacity of the reticulum and rumen in the ox but to the increased capacity of the third part of the stomach, the omasum.

These 3 factors, the nature of the carbohydrates eaten, the quantity eaten, and the quantity of food contained in the reticulum and rumen 
together, imply that fermentation in the rumen must proceed on a considerable scale. This conception is borne out by the results obtained by Hale, Duncan and Huffman (1940), who made an indirect estimate of the quantity of each constituent of the food that was digested in the rumen. Their method was to empty the rumen of a cow through a large rumen fistula 14 hours after a meal of hay; the ingesta were weighed and sampled and returned again to the rumen. The quantities of the various digestible constituents of the hay and of the indigestible lignin were measured, and a ratio was thus obtained. Similar ratios were determined for the material obtained from the rumen 14 hours after feeding and for the faeces. From these data it was calculated that, of the total digestible dry matter of the ration 90 per cent., and of the total quantity of cellulose digested 85 per cent., disappeared in the rumen. Even though the methods used are open to criticism their accuracy is sufficient to show that the importance of fermentation in the rumen overshadows the whole of the rest of the digestion in the alimentary tract, at any rate as regards carbohydrates, for there can be little doubt in the case of cellulose that disappearance from the rumen means fermentation within the rumen, since cellulose is insoluble, is intimately associated with lignin in the plant tissue, and is indigestible except with the aid of bacteria.

It was stated previously that a mixture of the lower fatty acids was the principal end product of the fermentations in the rumen and the evidence upon which this assertion is made must now be presented. It has been known for a long time that such a mixture is found in the rumen and in other places also, such as the large intestine of the horse and rabbit, where fermentation occurs but there was little evidence to show what acids made up the mixture, what relation the acids bore to the food, and what quantity of volatile acids was produced.

Beyond the fact that the mixture consisted of the lower fatty acids there was no sure information with which to answer the first question except for such deductions as could be made from distillation curves of the acids. It was not until Elsden (1945) employed the partition chromatogram for separating the individual acids that the first certain evidence was produced that the mixture consisted of acetic, propionic and butyric acids and that acetic acid predominated. In Table 1 are

TABLE 1

Volatile Fatty Acios in the Rumen of the Sheep

\begin{tabular}{|c|c|c|c|c|}
\hline \multirow[b]{2}{*}{ Sheep } & \multicolumn{4}{|c|}{ Acid expressed as millimols per $100 \mathrm{ml}$. rumen liquor } \\
\hline & Acetie & Propionic & Butyric & Total \\
\hline $\begin{array}{l}\mathbf{F} \\
\mathbf{F} \\
\mathbf{F} \\
\mathrm{C} \\
\mathrm{D} \\
\mathrm{E} \\
\mathbf{G} \\
\mathbf{W E} \\
W \mathrm{~F}\end{array}$ & $\begin{array}{l}5 \cdot 45 \\
3 \cdot 28 \\
8 \cdot 10 \\
1 \cdot 34 \\
7 \cdot 68 \\
7 \cdot 60 \\
2 \cdot 52 \\
1 \cdot 51 \\
3 \cdot 04\end{array}$ & $\begin{array}{l}1 \cdot 18 \\
1 \cdot 20 \\
3 \cdot 68 \\
0 \cdot 86 \\
2 \cdot 14 \\
2 \cdot 20 \\
0 \cdot 70 \\
0 \cdot 48 \\
0 \cdot 71\end{array}$ & $\begin{array}{l}0 \cdot 78 \\
0 \cdot 84 \\
2 \cdot 14 \\
1 \cdot 60 \\
1 \cdot 30 \\
2 \cdot 44 \\
0 \cdot 70 \\
0 \cdot 26 \\
0 \cdot 69\end{array}$ & $\begin{array}{r}7 \cdot 41 \\
5 \cdot 32 \\
13 \cdot 92 \\
3 \cdot 80 \\
11 \cdot 12 \\
12 \cdot 24 \\
3 \cdot 92 \\
2 \cdot 25 \\
4 \cdot 44\end{array}$ \\
\hline
\end{tabular}

VOL. 3,1945 ] 
given the results obtained by Elsden with the rumen contents from six individual sheep; part of the material, namely that from sheep $\mathrm{C}, \mathrm{E}$ and $G$, was obtained from the slaughter house while the remainder was obtained from living sheep provided with a permanent rumen fistula.

To the second question we have devoted considerable attention. We can say at once that only insignificant traces of volatile acids can be extracted from the food, for we have made aqueous extractions of various minced foodstuffs with boiling water and have found that the quantity of volatile acid appearing in the liquid after the solid matter had been strained off was negligible when compared with the quantity found in the rumen (Table 2).

TABLE 2

Volatile Acid Content of Foodstuffs Expressed as ACETIO ACID

\begin{tabular}{lll|c}
\hline \multicolumn{2}{c|}{ Foodstuff } & & $\begin{array}{c}\text { Acetic acid, g. per } \\
\text { l00 g. dry matter }\end{array}$ \\
\hline Hay . & $\ldots$ &. & $0 \cdot 12$ \\
Mangolds & $\ldots$ & $\ldots$ & $0 \cdot 33$ \\
Bran and oats & $\ldots$ & $\ldots$ & $0 \cdot 07$ \\
Grass .. & $\ldots$ &. & $0 \cdot 26$ \\
\hline
\end{tabular}

The relation between the time of feeding and changes in the concentration of total volatile acids in the rumen is marked. After feeding, the concentration increases and reaches a peak after an interval the length of which depends on the type of food given. When hay is given alone the rise is slow and the peak occurs within about 12 hours; if starchy food such as bran and oats is included the rise is more rapid and a peak is reached somewhat earlier and, if a food rich in sugar such as mangolds is given, the rise is more abrupt still and the peak is reached in 3 to 4 hours. Similar results can be obtained by introducing the individual carbohydrates directly into the rumen of a fasting sheep.

The effect of fasting is the reverse of that of feeding and, after the effect of the last meal has worn off, the volatile acid concentration falls steadily for 48 hours to a low but steady level which is maintained constant for as long as a week. This is due presumably to the slow fermentation of the less easily available cellulose which normally is not digested and which McAnally (1942) has shown to be present in straw.

The answer to the third question as to the quantity of volatile acid produced in the rumen leaves no doubt as to the importance of these acids as a nutrient. We have determined the total quantity of these acids in the rumen and reticulum of sheep taken straight from pasture and the results, expressed as g. acetic acid per $100 \mathrm{~g}$. dry matter, show plainly that these acids are important end products of fermentation. In a series of 10 sheep the concentration so expressed varied from 6.04 to $9 \cdot 75$. When it is recalled that the figure found for grass itself was only $0 \cdot 26 \mathrm{~g}$. per $100 \mathrm{~g}$. dry matter there can be no doubt that these acids are the result of bacterial fermentation taking place on an intensive scale. The total quantity of acids expressed as acetic acid found for the 10 sheep varied from $26 \cdot 8$ to $91.4 \mathrm{~g}$., the average figure being $64 \mathrm{~g}$. (Table 3). 
TABLE 3

Volathe Acid Content of the Ingesta Taken from the Reticulum and Rumen of Pasture Fed Shemp

\begin{tabular}{|c|c|c|c|c|}
\hline \multirow[b]{2}{*}{$\begin{array}{l}\text { Weight of } \\
\text { sheep } \\
\text { kg. }\end{array}$} & \multicolumn{2}{|c|}{ Ingesta } & \multicolumn{2}{|c|}{$\begin{array}{c}\text { Volatile acid expressed as } \\
\text { acetic acid }\end{array}$} \\
\hline & $\begin{array}{l}\text { Weight } \\
\text { kg. }\end{array}$ & $\begin{array}{c}\text { Dry } \\
\text { matter } \\
\text { per cent. }\end{array}$ & $\begin{array}{l}\text { Total } \\
\text { g. }\end{array}$ & $\begin{array}{l}\text { Per } 100 \mathrm{~g} \text {. } \\
\text { dry matter } \\
\mathrm{g} .\end{array}$ \\
\hline $55 \cdot 7$ & 5.90 & $15 \cdot 3$ & $55 \cdot 6$ & $6 \cdot 3$ \\
\hline $81 \cdot 1^{*}$ & 6.00 & $9 \cdot 6$ & $39 \cdot 8$ & $6 \cdot 8$ \\
\hline 76.8 & $7 \cdot 25$ & $11 \cdot 4$ & $65 \cdot 3$ & $7 \cdot 9$ \\
\hline $85 \cdot 9$ & 8.65 & $11 \cdot 3$ & $74 \cdot 9$ & $7 \cdot 6$ \\
\hline $82 \cdot 7^{*}$ & $5 \cdot 75$ & $5 \cdot 8$ & $26 \cdot 8$ & $8 \cdot 1$ \\
\hline $78 \cdot 6^{*}$ & $6 \cdot 85$ & $9 \cdot 7$ & $64 \cdot 8$ & $9 \cdot 7$ \\
\hline $63 \cdot 6$ & 10.90 & $12 \cdot 1$ & $91 \cdot 4$ & $6 \cdot 9$ \\
\hline $50 \cdot 9$ & $14 \cdot 45$ & $9 \cdot 2$ & $81 \cdot 1$ & $6 \cdot 1$ \\
\hline $58 \cdot 6$ & $7 \cdot 65$ & $10 \cdot 6$ & $55 \cdot 1$ & $6 \cdot 8$ \\
\hline $64 \cdot 1$ & 14.50 & $10 \cdot 0$ & $87 \cdot 6$ & $6 \cdot 0$ \\
\hline
\end{tabular}

* These animals were taken from pasture in the afternoon and kept in a box until the middle of the night before slaughter. In 2 of them the quantity of volatile acid is low.

The manner in which these acids becomo available to the animal is of considerable interest. When the concentration of volatile acid was determined in the various organs from the rumen to the rectum it was found that the concentration fell abruptly in the abomasum and, in this organ and in the small intestine, it was negligible. In the third part of the stomach, the omasum, the concentration was lower than in the rumen and reticulum but higher than in the abomasum (Table 4).

TABLE 4

Concentration of Volatile Acid throvghout the Alimentary Tract of the Sheep Expressed as g. Acetic Acid Per $100 \mathrm{~g}$. Dry Matter

\begin{tabular}{|c|c|c|c|c|c|}
\hline \multirow{2}{*}{\multicolumn{3}{|c|}{ Part of alimentary tract }} & \multicolumn{3}{|c|}{ Sheep no. } \\
\hline & & & 1 & 2 & 3 \\
\hline \multicolumn{3}{|l|}{ Rumen and reticulum } & $7 \cdot 93$ & $7 \cdot 64$ & $8 \cdot 07$ \\
\hline Omasum $\quad \ldots$ & . & . & $\mathrm{I} \cdot 44$ & $1 \cdot 12$ & $2 \cdot 14$ \\
\hline Abomasum $\quad \ldots$ & . & . & 0.21 & 0.11 & $0 \cdot 21$ \\
\hline \multicolumn{6}{|l|}{ Small intestine } \\
\hline \multicolumn{3}{|l|}{$\begin{array}{l}\text { oral } 2 / 3 \\
\text { caudal } 1 / 3\end{array}$} & $\begin{array}{l}0 \cdot 37 \\
0.77\end{array}$ & $\begin{array}{l}0.14 \\
0.96\end{array}$ & 0.3 \\
\hline $\begin{array}{l}\text { caudal } 1 / 3 \\
\text { Caecum } \ldots\end{array}$ & $\cdots$ & . & $3 \cdot 60$ & $4 \cdot 28$ & $4 \cdot 00$ \\
\hline \multicolumn{3}{|l|}{ Colon } & & & \\
\hline ascending limb & . & . . & $2 \cdot 88$ & $2 \cdot 11$ & $1 \cdot 88$ \\
\hline descending limb & . & . & $2 \cdot 64$ & $1 \cdot 57$ & $2 \cdot 11$ \\
\hline Rectum .. .. & . & . & $1 \cdot 95$ & $1 \cdot 66$ & $2 \cdot 02$ \\
\hline
\end{tabular}

Samples taken from the abomasum through a fistula at various times after feeding failed to show any significant rise in volatile acids. Similarly if doses of acetate or butyrate were introduced into the rumen and samples voc. 3,1045$]$ 
were taken from the rumen and abomasum at intervals, the concentration of volatile acid in the rumen fell within about 6 hours to the level prevailing before dosing, but no increase was found of the concentration in the abomasum. These facts led us to suppose that the acids must be absorbed directly from the rumen and reticulum and also from the omasum.

The possibility of absorption from the rumen had previously been explored by Trautmann (1933), who showed that drugs such as pilocarpine and atropine could pass into the blood stream through the stratified epithelium of the rumen. In order to throw fresh light on the subject we introduced the radio-opaque compound, sodium ortho-iodohippurate in solution into the empty rumen of lambs in which the exit from the reticulo-ruminal sac was closed by ligature. In these animals there was a slow absorption which was indicated by the accumulation of radio-opaque urine in the bladder. The presence of combined iodine in the urine was subsequently demonstrated chemically.

In order to obtain direct evidence as to whether or not the volatile acids themselves were absorbed from the rumen, blood draining the various parts of the stomach and intestine was withdrawn from sheep under nembutal anaesthesia and the concentration of volatile acids was determined by steam distillation. We found that blood draining the rumen carried a higher concentration of these acids than blood from any other part of the alimentary canal or than the peripheral blood (Table 5).

TABLE 5

Concentration of Volatile Acios in Peripheral Blood and in Blood from Different Parts of the Aljmentary Tract of the Shemp

\begin{tabular}{|c|c|c|c|c|c|c|c|c|c|}
\hline \multirow[b]{3}{*}{$\begin{array}{c}\text { Experi } \\
\text { ment } \\
\text { no. }\end{array}$} & \multicolumn{9}{|c|}{$\mathrm{N} / 10$ volatile acids, $\mathrm{ml}$. por $100 \mathrm{ml}$. blood } \\
\hline & \multirow[b]{2}{*}{$\begin{array}{c}\text { Carotid } \\
\text { artery }\end{array}$} & \multicolumn{8}{|c|}{ Venous blood } \\
\hline & & $\begin{array}{c}\text { Jugular } \\
\text { vein }\end{array}$ & $\begin{array}{l}\text { Pos- } \\
\text { terior } \\
\text { rumen }\end{array}$ & $\begin{array}{l}\text { An- } \\
\text { terior } \\
\text { rumen }\end{array}$ & $\begin{array}{c}\text { Reticu- } \\
\text { lum }\end{array}$ & $\begin{array}{l}\text { Oma- } \\
\text { sum }\end{array}$ & $\begin{array}{l}\text { Abom- } \\
\text { asum }\end{array}$ & $\begin{array}{c}\text { Small } \\
\text { intestine }\end{array}$ & $\begin{array}{l}\mathrm{Cae}- \\
\text { cum }\end{array}$ \\
\hline 1 & 5 & 0 & 38 & - & $\ldots$ & $-\cdots$ & 1 & 1 & 18 \\
\hline 2 & 2 & I & 31 & - & 一 & $\ldots$ & - & 2 & 11 \\
\hline 3 & - & 6 & 52 & - & 40 & 15 & 9 & - & - \\
\hline 4 & $\ldots$ & - & 17 & 51 & 28 & 23 & 2 & 一 & $\ldots$ \\
\hline 5 & 4 & 5 & 21 & $\ldots$ & $\ldots$ & - & - & 4 & 19 \\
\hline 6 & 4 & 5 & 22 & - & - & $\ldots$ & - & 4 & 20 \\
\hline 7 & 2 & 4 & 30 & $\ldots$ & - & 5 & l & I & 15 \\
\hline 8 & 4 & 4 & 20 & $\ldots$ & $\ldots$ & - & 2 & 二 & - \\
\hline 9 & $\ldots$ & - & 75 & - & - & 15 & - & $\longrightarrow$ & $\ldots$ \\
\hline 10 & - & - & 41 & 50 & $\ldots$ & - & - & - & 21 \\
\hline 11 & 10 & - & 45 & 88 & 40 & 27 & 7 & 8 & 22 \\
\hline 12 & 13 & 12 & 35 & - & - & - & - & - & 33 \\
\hline 13 & - & - & 55 & 109 & - & 26 & $\ldots$ & - & 40 \\
\hline 14 & - & - & 18 & 65 & - & 26 & - & - & - \\
\hline
\end{tabular}

Measurement of the blood flow in the posterior vein draining the rumen enabled us to obtain an estimate of the quantity of the acids absorbed and the results, calculated to represent the drainage from the whole of the reticulo-ruminal sac, gave us a value of 1 to $5 \mathrm{~g}$. an hour for the rate 
of absorption. This estimate is undoubtedly low because the blood draining the posterior part of the rumen carried a lower concentration of volatile acid than that draining the anterior part of the rumen and for this no allowance was made in the calculation.

It is not yet possible to account for the fermentation of carbohydrate in the rumen on a quantitative basis. We have shown that the quantity of volatile acids is large enough to make them of interest when the nutrition of the animal is considered as a whole. In addition we have shown not only that the quantity present is large but also that these acids are being absorbed continuously from the organs in which they are produced.

In order to assess the value of any product of bacterial digestion in the rumen it is necessary to know at what rate and in what quantity the nutrient in question becomes available to the animal. There are 2 ways for this; the first we have shown is by direst absorption, the second is by passage to the abomasum and absorption from the small intestine. Until the quantities of material passing by this latter route, from the stomach to the intestine, can be measured quantitatively no sure statement can be made as to the significance of the various nutrients which are produced in the rumen as a result of bacterial activity.

\title{
REFERENCES
}

Elsden, S. R. (1945). Biochem. J. 39, in the press.

Hale, E. B., Duncan, C. W. and Huffman, C. F. (1940). J. Dairy Sci. 23, 953.

MeAnally, R. A. (1942). Biochem. J. 36, 392.

Trautmann, A. (1933). Arch. Tierernähr. Tierz. 9, 178.

Washburn, L. E. and Brodie, S. (1937). Res. Bull. Mo. agric. Exp. Sla. no. 263.

\section{Volatile Fatty Acids in the Rumen of the Sheep}

\author{
Dr. S. R. Elsden (Agricultural Research Council Unit of Animal \\ Physiology, Department of Biochemistry, Cambridge)
}

Dr. Phillipson has drawn attention to the fact that there is a high concentration of volatile fatty acids in the rumen and that these are absorbed into the blood stream (Marshall and Phillipson, 1945). Sir Joseph Barcroft will discuss the fate of these compounds once they are absorbed (Barcroft, 1945). It is my purpose to describe some of the steps in the formation of these compounds, and the type of organism responsible for their formation.

Phillipson and McAnally (1942) showed that when various pure carbohydrates were introduced into the rumen of sheep, through a fistula, the carbohydrates disappeared and there was an increase in the concentration of volatile fatty acids, the rate of formation of which was dependent on the nature of the carbohydrate. Thus, glucose, fructose and sucrose were fermented very rapidly, and disappeared within 3 to 4 hours. Starch was fermented more slowly, and cellulose more slowly still. In addition, when glucose, fructose or sucrose was fermented, lactic acid was formed in quantity, only to be converted into volatile fatty acids.

\section{Production of Volatile Fatty Acids by Fermentation in Vivo}

The starting point of the work I am about to describe was a more detailed examination of the process of the fermentation of glucose by the voL. 3,1945 ] 